\author{
DEPARTMENT OF THE INTERIOR \\ UNITED STATES GEOLOGICAL SURVEY
}

\title{
MAP SHOWING SNOW AVALANCHE PROBABILITIES IN THE HENRYS LAKE QUADRANGLE, IDAHO AND MONTANA By
}

Irving J. Witkind, U.S. Geological Survey; Paul A. Hoskins, Vergil L. Lindsey, and E. L. Mitchell, U.S. Forest Service

FOLIO OF THE

HENRYS LAKE QUADRANGLE, IDAHO-MONTANA

MAP I-781-I

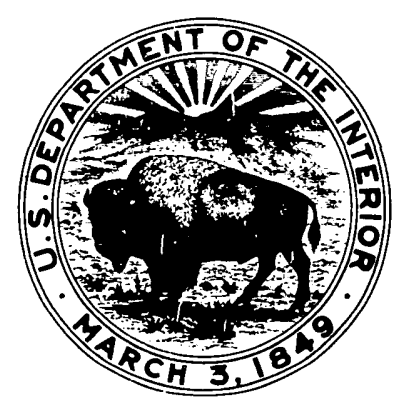

PUBLISHED BY THE U.S. GEOLOGICAL SURVEY 